\title{
Urologic manifestations of IgG4-related disease
}

\section{Manifestaciones urológicas de la enfermedad relacionada a IgG4}

DBenjamín Enrique Montaño-Roca, ${ }^{*}$ (DDavide Vanacore, ${ }^{2}$ (D) Gustavo Gallegos-Sánchez, ${ }^{1}$

iDCésar Eduardo Rosales-Velázquez, ${ }^{1}$ DGuillermo Enrique Ruvalcaba-Oceguera, ${ }^{1}$

(DMarco Antonio Aragón-Castro, ${ }^{1}$ iD Rubén Gutiérrez-Rosales, ${ }^{1}$ iD Romain Boissier. ${ }^{2}$

Keywords:

Pseudotumor,

IgG4, Urology,

Autoimmuneaccine.

\section{Abstract}

IgG4-related disease (IgG4-RD) is a clinical entity characterized by elevated serum IgG4 and tumor-like inflammation, with tissue infiltration by IgG4 and plasma cells. IgG4-RD is rare, but clinically significant, and its urologic manifestations have been reported in the literature. The present review covers a broad spectrum, describing the pathologies related to the area of urology.

In 2003, Terumi Kamisawa was the first to recognize IgG4-RD, characterized by multiorgan lesions in patients with autoimmune pancreatitis and classified as an inflammatory and fibrotic entity with a dense lymphoplasmacytic infiltrate, positive for IgG4. ${ }^{(1-3)}$ It presents in middle-aged patients, between 59-68 years of age, with no clear distribution by sex, ${ }^{(4-6)}$ and has different clinical presentations. The main urologic manifestations are inflammatory pseudotumors and lower urinary tract symptoms. The present article offers a clear, general overview of the disease, encompassing its pathophysiology, diagnosis, and treatment, from the perspective of urology.

Citation: Montaño Roca B.E., Vanacore D., Gallegos Sánchez G., Rosales Velázquez C.E., Ruvalcaba Oceguera G.E., Aragón Castro M.A. et al. Urologic Manifestations in IgG4-related disease. Rev. Mex. Urol. 2020;80(5):pp 1-10

Correspondence: *Benjamín Enrique Montaño Roca. Av. Baja Velocidad 284, San Jerónimo Chicahualco, 52170, Metepec, Edo. de México. Correo Electrónico: benjamín. mont@gmail.com
Received: 23/03/2020

Accepted: 01/07/2020

\footnotetext{
${ }^{1}$ Instituto de Seguridad Social del Estado de México y Municipios. Centro Médico Arturo Montiel Rojas, Toluca, México.

${ }^{2}$ Aix-Marseille Université, Marsella, Francia.
}

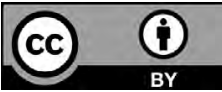




\section{Resumen}

La enfermedad relacionada con IgG4 (ER-IgG4) es una entidad clínica caracterizada por una concentración sérica elevada e inflamación similar a un tumor con infiltración de tejido por IgG4 y células plasmáticas. Aunque la ER-IgG4 es rara pero clínicamente significativa, sus manifestaciones urológicas se han reportado en la literatura. Esta revisión ofrece un panorama completo que explica las patologías relacionadas en el área urológica.

Desde que Terumi Kamisawa reconoció por primera vez la ER-IgG4 en el año 2003, caracterizada por lesiones multiorgánicas en pacientes con pancreatitis autoinmune, clasificada como una entidad inflamatoria y fibrótica con tumores e infiltración linfoplasmocítica densa, positiva a IgG4. ${ }^{(1-3)}$ Presentada en población de mediana edad, entre 59-68 años, sin una distribución clara del sexo, ${ }^{(4-6)}$ se presenta con diversas manifestaciones clínicas y como manifestación urológica principal tumores pseudoinflamatorios y sintomatología de tracto urinario bajo.

Palabras clave:

Pseudotumor, IgG4, Urología, Autoinmune.
Esta revisión ofrece una visión general y clara de la enfermedad desde la fisiopatología, el diagnóstico y el tratamiento desde un punto de vista urológico

\section{Introduction}

IgG4 is an antibody with a unique structure and function and makes up less than $5 \%$ of the total IgG in healthy individuals. In contrast to IgG1, 2, and 3, serum IgG4 concentrations in healthy persons vary by a factor of more than 100 (reference values from 0.01 to $1.4 \mathrm{mg} / \mathrm{dl}$ ) but IgG4 values do not generally fluctuate in individual persons. ${ }^{(1)}$

IgG4 binds weakly to the complement component (C1) and Fc receptors and does not play an active role in immune activation.

The diagnostic criteria were proposed by the Japanese study group and validated for the worldwide population.

Table 1. Diagnostic criteria validated in a Japanese population (Japanese Health Ministry guidelines). ${ }^{(7)}$ Adapted from Umehara H. et al.

\begin{tabular}{|c|l|}
\hline Clinical criteria & \multicolumn{1}{|c|}{ Local or diffuse inflammation in one or multiple organs } \\
\hline Serologic criteria & IgG4 concentration $>135 \mathrm{mg} / \mathrm{dl}(1.35 \mathrm{~g} / \mathrm{dl})$ \\
\hline Histopathologic criteria & Extensive lymphocytic infiltration, plasma cells, and tissue fibrosis \\
& with IgG4:IgG ratio over $40 \%$, and IgG4 $\geq 10$ plasma cells per each \\
& IgG4/HPF \\
\hline
\end{tabular}

Continúa... 


\begin{tabular}{|c|l|}
\hline Clinical criteria & \multicolumn{1}{|c|}{ Local or diffuse inflammation in one or multiple organs } \\
\hline Conditions & $\begin{array}{l}\text { Definitive disease: fulfilling all criteria } \\
\text { Probable disease: fulfilling clinical and histopathologic criteria } \\
\text { Possible: fulfilling clinical and serologic criteria only }\end{array}$ \\
\hline Differential diagnosis & Malignant tumors, such as lymphoma or cancer \\
& Sjögren's syndrome \\
& Primary sclerosing cholangitis \\
& Castleman's disease \\
& Secondary retroperitoneal fibrosis \\
& Granulomatosis with polyangiitis (Wegener's granulomatosis) \\
& Sarcoidosis \\
& Eosinophilic granulomatosis with polyangiitis (Churg-Strauss syndrome). \\
\hline
\end{tabular}

\section{Pathogenesis}

Two patterns have been described in IgG4-RD: autoimmune and allergic. IgG4 plays a role in allergen tolerance and the response to infectious agents.

The physiologic function of IgG4 is not well understood, nor how it acts as an autoantigen or antibody.

An elevated serum level is not exclusive of IgG4-RD, given that it is also elevated in Castleman's multicentric disease, allergies, and eosinophilic granulomatosis with polyangiitis (Churg-Strauss syndrome). (8,9) $^{(2,0)}$

In relation to autoimmunity, the best example is autoimmune pancreatitis, the prototypical disorder for IgG-RD. Antinuclear antibodies have been identified in some cases, as have antibodies against lactoferrin and carbonic anhydrase II, but there is no conclusive evidence that it is an autoimmune disease. ${ }^{(7)}$

The physiologic response of IgG4 may occur due to chronic and repeated antigen exposure. Its production is similar to the values of IgE controlled by Th2 and cytokines, such as interleukin (Il) 4 and 13, that stimulate the both IgG4 and IgE production. Contrastingly, Il-10, 12, and 21, maintain a balance between them and when it is lost, disease tends to present. $^{(1)}$

\section{Pathology}

Histopathologic biopsy study is the cornerstone of the IgG4-RD diagnosis. Serum IgG4 levels may be useful in guiding toward the diagnosis, but no specific serum marker has been identified.

The morphologic hallmark in the disease is described as a dense lymphoplasmacytic infiltrate organized in a storiform manner, phlebitis obliterans, and eosinophilic infiltrate. In glandular organs, the infiltrate tends to aggregate around ductal structures and the inflammatory lesion frequently forms a tumor-like mass that destroys the affected organ.

Immunohistochemistry is required for its identification because there is disagreement on certain points for making the diagnosis (10 to 50 affected cells/HPF).

Clinical experience is needed to identify early-stage disease because its characteristic fibrosis presents in the advanced stages (e.g., retroperitoneal involvement). Another important criterion is identifying a difference of at least $50 \%$ or more in the $\operatorname{IgG} 4 / \operatorname{IgG}$ ratio. ${ }^{(7,10)}$ 
Histopathologically, lymphoma is the disease that most resembles IgG4-RD, and clonality studies are needed to differentiate them. The characteristic difference between lymphomas and IgG4-RD is B-cell infiltration and T-cell infiltration respectively. ${ }^{(2)}$

\section{Pathophysiology}

\section{Genetic risk factors}

HLA serotypes have been identified in a Japanese population with IgG4-RD:

- DRB $1 * 0405$

- DQB1*0401

The presence of these serotypes has been reported to possibly raise the likelihood of presenting with the disease. HLA DQß1-57, without aspartic acid, was observed in a Korean population. ${ }^{(3)}$

Single nucleotide variants in non-HLA-related genes and a nucleotide have been identified as recurrence and susceptibility factors, which translate to proteins, such as antigen 4 , that are associated with cytotoxic T lymphocytes, TNF-alpha, and the constant fraction of the type 3 receptor. ${ }^{(2)}$

Some non-HLA risk genes for extrapancreatic lesions have been proposed by Ishikawa and Terao, such as: ${ }^{(11)}$

- CXCR3

- MLL3

- TNF- $\boldsymbol{\alpha}$ promoter

\section{Bacterial infection}

Homology has been described between human carbonic anhydrase and the alfa carbonic anhydrase of Helicobacter pylori and their homo- logous segments join to the HLA DRB1*0405, activating the immune system. A connection exists between the plasminogen protein-ligand of Helicobacter pylori and ubiquitin ligase $\mathrm{E}$ with the n-recognin 2 component that pancreatic acinar cells express, showing a correlation between an infectious agent and the development of autoimmune pancreatitis. No other bacteria are associated with the development of the disease. $^{(1)}$

\section{Autoimmunity}

Serum IgG4 in patients with IgG4-RD attaches to the pancreatic, biliary, and salivary ductal epithelium, also affecting the retroperitoneum, testes, and prostate, among many others. Autoantigens against carbonic anhydrase, lactoferrin, and pancreatic secretory trypsinogen inhibitors that express antibodies against different exocrine organs, have been identified in those organs and are related to the clinical manifestations mentioned in the following section.

An autoantigen (protein 13.1-kD) was identified in a proteomic analysis of 28 patients with IgG4-RD, but no direct correlation has been established with the disease. ${ }^{(12)}$

\section{Clinical manifestations}

IgG4 has diverse clinical manifestations in $60-90 \%$ of patients, due to its multiorgan involvement. It generally manifests as tumor-like masses in the affected organs. For example, renal lesions resemble carcinomas, pulmonary involvement produces nodular lesions, and pancreatic lesions have diffuse growth. Lymphadenopathy and asthma or allergy symptoms 
are present in approximately $40 \%$ of cases, without systemic inflammatory response or constitutional symptoms. ${ }^{(2)}$

Many disorders have been identified that can be associated with the IgG4-RD spectrum: ${ }^{(2)}$

Table 2 Urologic manifestations of IgG4-related disease

\begin{tabular}{|c|c|}
\hline Clinical condition & Organ or glands involved \\
\hline $\begin{array}{l}\text { Mikulicz syndrome } \\
\text { and Küttner's tumor }\end{array}$ & Salivary glands \\
\hline $\begin{array}{l}\text { Riedel's thyroiditis and } \\
\text { Hashimoto's thyroiditis }\end{array}$ & Thyroid \\
\hline $\begin{array}{l}\text { Eosinophilic } \\
\text { angiocentric fibrosis }\end{array}$ & $\begin{array}{l}\text { Paranasal sinuses, } \\
\text { lacrimal glands, and } \\
\text { lower respiratory tract }\end{array}$ \\
\hline Multifocal fibroelastosis & $\begin{array}{c}\text { Lungs, pleura, and } \\
\text { heart valves }\end{array}$ \\
\hline $\begin{array}{l}\text { Inflammatory } \\
\text { pseudotumor }\end{array}$ & $\begin{array}{c}\text { Kidney, ureter, bladder, } \\
\text { prostate, testes }\end{array}$ \\
\hline Mediastinal fibrosis & Mediastinum \\
\hline $\begin{array}{l}\text { Retroperitoneal fibrosis } \\
\text { (Ormond's disease) }\end{array}$ & Retroperitoneum \\
\hline $\begin{array}{l}\text { Sclerosing periaortitis } \\
\text { and periarteritis }\end{array}$ & $\begin{array}{l}\text { Aorta and its main } \\
\text { branches }\end{array}$ \\
\hline $\begin{array}{l}\text { Inflammatory aortic } \\
\text { aneurysm }\end{array}$ & Aorta \\
\hline $\begin{array}{l}\text { Hypocomplementemic } \\
\text { tubulointerstitial } \\
\text { nephritis with } \\
\text { idiopathic } \\
\text { tubulointerstitial } \\
\text { deposits }\end{array}$ & Kidney \\
\hline Hypopituitarism & Pituitary \\
\hline Pachymeningitis & Meninges \\
\hline $\begin{array}{l}\text { Constrictive } \\
\text { pericarditis }\end{array}$ & Pericardium \\
\hline
\end{tabular}

\section{Kidneys}

The most common renal manifestation is tubulointerstitial nephritis. ${ }^{(5)}$ When severity is moderate, it is clinically silent and always focal. Contrasted computed tomography (CT) reveals increased kidney size and areas with poor contrast uptake. ${ }^{(6)}$ Nevertheless, it is important to differentiate those lesions from renal carcinoma, especially papillary cell carcinoma and metastasis.

In some cases, lesions associated with IgG4-RD are found in the renal hilum, where the blood vessels, nerves, and ureters enter or exit the kidney. Fifty percent of patients can develop secondary hydronephrosis. ${ }^{(13)}$

Few case series have been reported with renal involvement. In 2007, Saeki et al. ${ }^{(14)}$ presented 7 cases documented within the time frame of 1996 to 2006. All the patients were male, with elevated serum IgG4. Three isolated renal patterns were observed: extraparenchymal hydronephrosis associated with retroperitoneal lesions, tubulointerstitial nephritis, and a lymphoplasmacytic lesion in the renal interstitium.

Interstitial nephritis was confirmed in 4 cases, two of which showed diffuse inflammation on the CT scan and elevated levels of serum $ß 2$ microglobulin and N-acetyl- $ß$-D-glucosaminidase, common in diffuse interstitial nephritis. Dense and focal lesions were found in another case. Scintigraphy studies with Gallium 67 showed accumulation in both kidneys and there was a decline in renal function after the study.

Murashima et al. ${ }^{(15)}$ reported two cases of tubulointerstitial nephritis with multiple renal nodules, whose histopathology studies showed lymphocytes and plasma cells with fibrosis. Rudmik described autoimmune pancreatitis with renal lesions that resembled metastasis. ${ }^{(16)}$

Most cases with renal involvement had a history of pancreatic disease, but isolated di- 


\section{Manifestaciones urológicas de la enfermedad relacionada a lgG4. Montaño-Roca B., E, et al.}

sease has also been reported and may or may not be associated with renal insufficiency. ${ }^{(17)}$

\section{Retroperitoneal fibrosis}

Some small case series have reported retroperitoneal fibrosis as a manifestation of IgG4-RD.

Before considering IgG4-RD diagnosis, drug-related adverse effects should be ruled out, (e.g., bromocriptine, ergotamine, propranolol, timolol, aspirin, acetaminophen, haloperidol, and sulfonylureas). In isolated disease or that accompanying other classic manifestations (e.g., autoimmune pancreatitis, periaortitis), the most commonly compromised regions in the retroperitoneum are the thoracic and lumbar areas, affecting the abdominal aorta and its main branches and ureters. ${ }^{(18)}$

Initial clinical manifestations are progressive, colicky lumbar pain that decreases with nonsteroidal anti-inflammatory drugs (NSAIDs). Uremia presents in advanced stages. ${ }^{(19,20)}$

Elevated inflammatory markers, such as the erythrocyte sedimentation rate (ESR), C-reactive protein (CRP), and anemia of chronic disease have been found, as isolated data. In advanced stages, $60 \%$ of patients present with antinuclear antibodies. Periaortitis can progress to aortic aneurysms or hydronephrosis, usually bilateral, as late manifestations of the disease. ${ }^{(21,22)}$

\section{Ureters}

Very few cases have been reported with compromised ureters. Terms such as inflammatory pseudotumor or idiopathic segmental urethritis were used in the past to refer to IgG4-RD.
${ }^{(23,24)}$ In 2013, Marando et al. ${ }^{(25)}$ reviewed two cases with pseudotumors in ureters consistent with IgG4-RD due to its histologic and serologic characteristics, in addition to carrying out a retrospective analysis of the other 40 cases in the literature that could have been cases of IgG4-RD, before it was described as a disease. Those authors reclassified the cases that had complete medical records and fulfilled all the diagnostic criteria.

\section{Bladder}

In a study by Crumley et al., ${ }^{(26)}$ they analyzed a subgroup of 44 cases of interstitial cystitis with IgG4 plasma cells affecting bladder tissue, but only 4 cases fulfilled all the criteria for IgG4-RD.

Interstitial nephritis tends to be more frequent in women, but a study showed that men with positive IgG4 were more commonly affected, at $26 \%$, with an average age of 60 , whereas $8 \%$ of men with negative IgG4 and a mean age of 41.1, presented with the disease. The association with age, but not sex, was statistically significant. A decrease in bladder capacity under anesthesia was more common in patients with IgG4-positive cells, $33 \%$ vs. $0 \%$, establishing IgG4-associated fibrosis. By highlighting the positive cases with higher inflammation, storiform fibrosis, more than 30 plasma cells/ $\mathrm{HPF}$, and a $\operatorname{IgG} 4 / \operatorname{IgG}$ ratio over $50 \%$, those authors concluded that the presence of IgG4 plays an important role in interstitial nephritis. The disadvantages in that study were its small size, no case-control design, and the fact that only 4 cases fulfilled the diagnostic criteria, but it paves the way for further research on that renal pathology. ${ }^{(27)}$ 
Prostate

Patients with prostatic involvement commonly present with symptoms of benign prostatic hyperplasia (BPH), incomplete voiding, increased frequency, intermittency, urinary urgency, nocturia, and a weak urinary stream, and are commonly diagnosed with chronic prostatitis. (28-30) Reported cases include manifestations of lower urinary tract symptoms with normal prostate-specific antigen (PSA) levels.

There is limited data on the involvement of the lower urinary tract. Most studies are on Asian populations. Symptoms and age of presentation of $\mathrm{BPH}$ are the same as for IgG4-RD, thus multiorgan involvement, especially of the pancreas, should raise diagnostic suspicion. ${ }^{(31)}$

\section{Urethra}

In the study by Williamson et al., ${ }^{(32)} 38$ urethral caruncle biopsies were analyzed to understand the etiology and determine a possible treatment for that disorder. Immunohistochemistry was carried out to evaluate different types of etiology, including viral and autoimmune causes. Four patients (11\%) had more than 50 cells/ HPF that were positive for IgG4 and an IgG4/ IgG ratio over $50 \%$, whereas the other patients presented with few or no IgG4-positve cell infiltrate $(<10)$. A comparison was made with another analysis, composed of 21 case-control studies, in which no inflammatory infiltration was observed, and the diagnostic criteria were not fulfilled for IgG4-RD. Stromal fibrosis and chronic inflammation were found in the four cases of the Williamson study, but none of them presented with any clinical manifesta- tions of the disease or a viral etiology. Therefore, some cases of urethral caruncle could be related to IgG4-RD, and it should be considered a diagnostic option with the abovementioned clinical manifestations.

\section{Testes}

In 2012, Hart et al. ${ }^{(33)}$ carried out the first case report of testicular pseudotumor in IgG4$\mathrm{RD}$, describing a patient in the Mayo Clinic. He had a history of autoimmune pancreatitis, was diabetic with difficult glycemic control, and presented with retroperitoneal fibrosis and hydronephrosis. Adequate clinical control was achieved utilizing prednisone. After those events, the patient presented with the rapid growth of a painful, right testicular mass and no related urinary symptoms. An ultrasound study revealed a multi-septated, fluid-filled mass, measuring $5 \times 5 \times 5.1 \mathrm{~cm}$. Upon resection, its testicular origin was observed. The histologic study reported the classic findings of IgG4-RD. Few related cases have since been reported. Maillet et al. ${ }^{(34)}$ presented a patient with a similar history, first presenting with a left testicular mass that was managed through orchiectomy. One month later he presented with a right testicular mass with the same characteristics, that was managed in exactly the same way. The manifestation of testicular masses with the presence or history of autoimmune pancreatitis or other characteristics of IgG4-RD should raise high suspicion of the disease. ${ }^{(35)}$ The only treatment reported in those cases was resection and no therapeutic trials with anti-inflammatory drugs were carried out due to the high suspicion of malignancy. ${ }^{(36)}$ 


\section{Conclusion}

The present literature review offers key elements to nephrologists, urologists, and pathologists, that can aid in the early diagnosis of this new and emerging disease in the area of urology, describing its pathophysiology, important clinical data, and appropriate treatment.

\section{References}

1. Stone JH, Zen Y, Deshpande V. IgG4Related Disease. N Engl J Med. 2012 Feb 9;366(6):539-51. doi: https://doi.org/10.1056/ nejmra1104650

2. Kamisawa T, Zen Y, Pillai S, Stone JH. IgG4-related disease. The Lancet. 2015 Apr;385(9976):1460-71. doi: https://doi. org/10.1016/s0140-6736(14)60720-0

3. Khosroshahi A, Stone JH. A clinical overview of IgG4-related systemic disease: Current Opinion in Rheumatology. 2011 Jan;23(1):57-66. doi: https://doi.org/10.1097/ bor.0b013e3283418057

4. Kamisawa T, Funata N, Hayashi Y, Eishi Y, Koike M, Tsuruta K, et al. A new clinicopathological entity of IgG4-related autoimmune disease. Journal of Gastroenterology. 2003 Oct 1;38(10):982-4. doi: https://doi.org/10.1007/ s00535-003-1175-y

5. Saeki T, Saito A, Yamazaki H, Emura I, Imai $\mathbf{N}$, Ueno $\mathbf{M}$, et al. Tubulointerstitial nephritis associated with IgG4-related systemic disease. Clin Exp Nephrol. 2007 Jun 1;11(2):168-73. doi: https://doi.org/10.1007/s10157-007-0464-9

6. Shoji S, Nakano M, Usui Y. IgG4-related inflammatory pseudotumor of the kidney. Int J Urol. 2010 Apr;17(4):389-90. doi: https://doi. org/10.1111/j.1442-2042.2010.02483.x
7. Umehara H, Okazaki K, Masaki Y, Kawano M, Yamamoto M, Saeki T, et al. Comprehensive diagnostic criteria for IgG4-related disease (IgG4-RD), 2011. Mod Rheumatol. 2012 Feb 1;22(1):21-30. doi: https://doi.org/10.1007/ s10165-011-0571-Z

8. Wallace ZS, Deshpande V, Mattoo H, Mahajan VS, Kulikova M, Pillai S, et al. IgG4-Related Disease: Clinical and Laboratory Features in One Hundred Twenty-Five Patients: CLINICAL AND LABORATORY FEATURES OF IgG4RELATED DISEASE. Arthritis \& Rheumatology. 2015 Sep;67(9):2466-75. doi: https://doi. org/10.1002/art.39205

9. Deheragoda MG, Church NI, RodriguezJusto M, Munson P, Sandanayake N, Seward EW, et al. The Use of Immunoglobulin G4 Immunostaining in Diagnosing Pancreatic and Extrapancreatic Involvement in Autoimmune Pancreatitis. Clinical Gastroenterology and Hepatology. 2007 Oct;5(10):1229-34. doi: https://doi.org/10.1016/j.cgh.2007.04.023

10. Palazzo E, Palazzo C, Palazzo M. IgG4-related disease. Joint Bone Spine. 2014 Jan;81(1):2731. doi: https://doi.org/10.1016/j. jbspin.2013.06.001

11. Ishikawa Y, Terao C. Genetic analysis of IgG4related disease. Modern Rheumatology. 2020 Jan 2;30(1):17-23. doi: https://doi.org/10.108 0/14397595.2019.1621000

12. Yamamoto M, Naishiro Y, Suzuki C, Kokai Y, Suzuki R, Honda S, et al. Proteomics analysis in 28 patients with systemic IgG4-related plasmacytic syndrome. Rheumatol Int. 2010 Feb;30(4):565-8. doi: https://doi.org/10.1007/ s00296-009-1030-4

13. Hamanou $\mathbf{H}$, Kawa S, Ochi Y, Unno $\mathbf{H}$, Shiba N, Wajiki M, et al. Hydronephrosis associated with retroperitoneal fibrosis and sclerosing pancreatitis. The Lancet. 2002 
Apr;359(9315):1403-4. doi: https://doi. org/10.1016/s0140-6736(02)08359-9

14. Saeki T, Nishi S, Ito T, Yamazaki $H$, Miyamura S, Emura I, et al. Renal Lesions in IgG4-Related Systemic Disease. Intern Med. 2007;46(17):1365-72. doi: https://doi. org/10.2169/internalmedicine.46.0183

15. Murashima M, Tomaszewski J, Glickman JD. Chronic Tubulointerstitial Nephritis Presenting as Multiple Renal Nodules and Pancreatic Insufficiency. American Journal of Kidney Diseases. 2007 Jan;49(1):e7-10. doi: https:// doi.org/10.1053/j.ajkd.2006.10.025

16. Rudmik L. Autoimmune pancreatitis associated with renal lesions mimicking metastatic tumours. Canadian Medical Association Journal. 2006 Aug 15;175(4):367-9. doi: https://doi. org/10.1503/cmaj.051668

17. Divatia M, Kim SA, Ro JY. IgG4-Related Sclerosing Disease, an Emerging Entity: A Review of a Multi-System Disease. Yonsei Med J. 2012;53(1):15. doi: https://doi.org/10.3349/ ymj.2012.53.1.15

18. Fairweather J, Jawad ASM. Immunoglobulin G4-related Retroperitoneal Fibrosis: A New Name for an Old Disease. Urology. 2013 Sep;82(3):505-7. doi: https://doi. org/10.1016/j.urology.2013.05.012

19. Hamanou H, Kawa S, Ochi Y, Unno H, Shiba N, Wajiki M, et al. Hydronephrosis associated with retroperitoneal fibrosis and sclerosing pancreatitis. The Lancet. 2002 Apr;359(9315):1403-4. doi: https://doi. org/10.1016/s0140-6736(02)08359-9

20. Fernández-Codina A, Martínez-Valle F, CastroMarrero J, De Torres I, Vilardell-Tarrés M, Ordi-Ros J. Idiopathic retroperitoneal fibrosis: IgG4 infiltration in a cohort of Spanish patients. Rheumatol Int. 2014 Sep;34(9):1263-5. doi: https://doi.org/10.1007/s00296-013-2936-4
21. Sakamoto A, Nagai R, Saito K, Imai Y, Takahashi M, Hosoya Y, et al. Idiopathic retroperitoneal fibrosis, inflammatory aortic aneurysm, and inflammatory pericarditisRetrospective analysis of 11 case histories. Journal of Cardiology. 2012 Mar;59(2):139-46. doi: https://doi.org/10.1016/j.jjcc.2011.07.014

22. Ellimoottil C, Hart S, Mehta V, Quek ML. Localized Perirenal Retroperitoneal Fibrosis. Urology. 2013 Apr;81(4):e27-8. doi: https:// doi.org/10.1016/j.urology.2013.01.004

23. Moriarty MA, Dahmoush L, Nepple KG. IgG4 Related Disease of the Ureter (Inflammatory Pseudotumor). Journal of Urology. 2014 Apr;191(4):1126-7. doi: https://doi. org/10.1016/j.juro.2014.01.015

24. Kim SA, Lee S-R, Huh J, Shen SS, Ro JY. IgG4associated inflammatory pseudotumor of ureter: clinicopathologic and immunohistochemical study of 3 cases. Human Pathology. 2011 Aug;42(8):1178-84. doi: https://doi. org/10.1016/j.humpath.2010.03.011

25. Marando A, D'Ambrosio G, Catanzaro F, La Rosa S, Sessa F. IgG4-related disease of the ureter: report of two cases and review of the literature. Virchows Arch. 2013 Jun;462(6):6738. doi: https://doi.org/10.1007/s00428-0131421-5

26. Crumley S, Ge Y, Zhou H, Shen SS, Ro JY. Interstitial cystitis: another IgG4-related inflammatory disease? Annals of Diagnostic Pathology. 2013 Oct;17(5):403-7. doi: https:// doi.org/10.1016/j.anndiagpath.2013.03.004

27. Park S, Ro JY, Lee DH, Choi SY, Koo H. Immunoglobulin G4-associated inflammatory pseudotumor of urinary bladder: a case report. Annals of Diagnostic Pathology. 2013 Dec;17(6):540-3. doi: https://doi. org/10.1016/j.anndiagpath.2013.01.004 


\section{Manifestaciones urológicas de la enfermedad relacionada a IgG4. Montaño-Roca B., E, et al.}

28. Hart PA, Smyrk TC, Chari ST. IgG4-related prostatitis: a rare cause of steroid-responsive obstructive urinary symptoms. Int J Urol. 2013 Jan;20(1):132-4. doi: https://doi.org/10.1111/ j.1442-2042.2012.03194.X

29. Bourlon MT, Sánchez-Ávila M, ChabléMontero F, Arceo-Olaiz R. IgG4-Related Autoimmune Prostatitis: Is It an Unusual or Underdiagnosed Manifestation of IgG4-Related Disease? Case Reports in Urology. 2013;2013:15. doi: 10.1155/2013/295472

30. Nishimori I, Kohsaki T, Onishi S, Shuin T, Kohsaki S, Ogawa Y, et al. IgG4-related Autoimmune Prostatitis: Two Cases with or without Autoimmune Pancreatitis. Intern Med. 2007;46(24):1983-90. doi: https://doi. org/10.2169/internalmedicine.46.0452

31. Uehara T, Hamano H, Kawakami M, Koyama M, Kawa S, Sano K, et al. Autoimmune pancreatitis-associated prostatitis: Distinct clinicopathological entity: IgG4-related prostatitis. Pathology International. 2008 Jan 10;58(2):118-25. doi: https://doi.org/10.1111/ j.1440-1827.2007.02199.x

32. Williamson SR, Scarpelli M, Lopez-Beltran A, Montironi R, Conces MR, Cheng L. Urethral caruncle: a lesion related to IgG4-associated sclerosing disease? J Clin Pathol. 2013 Jul;66(7):559-62. doi: https://doi.org/10.1136/ jclinpath-2012-201218
33. Hart PA, Moyer AM, Yi ES, Hogan MC, Pearson RK, Chari ST. IgG4-related paratesticular pseudotumor in a patient with autoimmune pancreatitis and retroperitoneal fibrosis: an extrapancreatic manifestation of IgG4-related disease. Human Pathology. 2012 Nov;43(11):2084-7. doi: https://doi. org/10.1016/j.humpath.2012.05.017

34. de Buy Wenniger LM, Scheltema JM, Verheij J, Beuers U. Testicular Inflammation as a New Manifestation of IgG4-associated Disease. Urology. 2013 Aug;82(2):e15-6. doi: https:// doi.org/10.1016/j.urology.2013.04.046

35. Bösmüller $\mathbf{H}$, von Weyhern $\mathbf{C H}$, Adam $\mathbf{P}$, Alibegovic V, Mikuz G, Fend F. Paratesticular fibrous pseudotumor-an IgG4-related disorder? Virchows Arch. 2011 Jan;458(1):109-13. doi: https://doi.org/10.1007/s00428-010-0995-4

36. Dieckmann K-P, Struss WJ, Frey U, NahlerWildenhain M. Paratesticular fibrous pseudotumor in young males presenting with histological features of IgG4-related disease: two case reports. J Med Case Reports. 2013 Dec;7(1):225. doi: https://doi. org/10.1186/1752-1947-7-225 